\title{
The Single And Plural Phrases in Matthew 4:16 and Their Meanings
}

\section{Adi Putra}

Pelita Dunia Theological Seminary, Indonesia

Email:addiepoetra7@gmail.com

\begin{abstract}
:
Matthew 4:16 finds both singular and plural phrases. This phrase is very interesting to study because the context of this verse is in Galilee, a place where Jesus spent most of his time serving. Through qualitative research with an exegetical study approach, the researcher found that the results and conclusions were that the purpose of singular and plural phrases in these verses was: a singular phrase for Jews and a plural phrase for other nations. Thus, it can provide the theological understanding that Jesus' mission in

Galilee was not only for the Jews who were there, but also for other nations who had long settled there even before the time of Jesus.
\end{abstract}

Article History:

Received: 26 September 2020

Accepted: 13 January 2021

Keywords:

Matthew;

Galilee;

Jesus' Mission

\section{Introduction}

Matthew 4:16 is part of passage 4: 12-17 that wants to emphasize the beginning of the ministry of the Lord Jesus to the North, especially the Galilee region. When you look at verse 16, this verse is actually quoted by the gospel writer Matthew from Isaiah 8: 23-9: 1. Just like the title of this article, that there are actually quite interesting things that may often be underestimated or ignored by the readers of this passage, namely: there are singular and plural phrases in the verse.

Does this represent the demographic situation of the Galilee region? Where as a large group can be categorized into two major parts, namely: the Jewish nation and other nations. This will try to be answered and described in this article. At the same time, this research will find out that the mission carried out by Jesus in Galilee was for the Israelites and also other nations in the Galilee region. However, the above assumptions will be confirmed by the results of this study.

If this is the case, then in fact Jesus when giving orders to His disciples to preach the gospel to other nations, actually He has given that model of service. In a sense, the mission of Jesus to Galilee has become a 'forerunner' or perhaps more precisely 'model' of the mission of the Apostles and even the Church in the future. So it might also be incorrect to say that Jesus' mission when incarnated was exclusively aimed at the Jews. Because, in fact, other nations 
turned out to be the object of Jesus' mission. Although this can also be categorized as an effect due to the rejection of the Jewish people to Jesus' mission.

In this lesson using qualitative methods. Where is more specific or focuses on longeur review to obtain more valid and correct results. The qualitative method referred to here is text exegesis. Where researchers focus more on exegetical studies by paying attention to information and data from literature, journal articles, to other literature sources. According to Osborne, exegesis is an approach taken to find "what it meant" or the past meaning of a text. ${ }^{1}$

Thus, researchers are interested in researching Jesus 'mission to Galilee, especially to see the object of Jesus' mission there. Can it be justified in the assumption that the mission also served the Gentiles there? Or was it exclusively for the Jews there? Through this investigation, it is expected to be able to answer and provide the right answer. That is the reason this research focuses more on the text of Matthew 4:16 in order to know the meaning of the singular and plural phrases that appear in the verse.

\section{Result and Discussion}

\section{The Context of Matthew 4:16}

Verse 16 is an inseparable part of verses 12-17. That is in seeing the context, it cannot be separated from verses $12-17$. In this passage (4: 12-17) it shows that the time has come for the Lord Jesus to start His Messianic mission. Like Mark's the Gospel, Matthew's Gospel begins this story after John the Baptist is said to be imprisoned. Chapters 4: 12-17 are short passages that function as narratives that emphasize the transition or introduction of the ministry of the Lord Jesus in Galilee. Hagner stated, the work of Jesus which now begins preceded by quotations from the Old Testament using the formula of fulfillment functions as a rubric for the entire ministry of the Lord Jesus in Galilee. ${ }^{2}$

Blomberg argued, "This is the last passage in Matthew's overall introduction to the ministry of Jesus. The main body of the Gospel begins in 4:17 as Jesus 'from that time on began to teach' his message of the kingdom throughout Galilea" ${ }^{3}$ For Blomberg, this section is the last part of the entire introductory part of Matthew to the ministry of the Lord Jesus. Because later

\footnotetext{
${ }^{1}$ Grant R Osborne, The Hermeneutical Spiral: A Comprehensive Introduction to Biblical Interpretation (USA: InterVarsity Press, 2006), 22.

${ }^{2}$ Donald A. Hagner, Word Biblical Commentary (WBC): Matthew 1-13 (Printed in Colombia: Nelson Reference and Electronic, 1993), 71 .

${ }^{3}$ Craig L. Blomberg, Matthew on Commentary on The New Testament Use of The Old Testament (Grand Rapids, Michigan: Baker Academic, 2007), 18.
} 
in 4:17, only seen as the beginning of the ministry of the Lord Jesus by teaching about the kingdom of God in all regions of Galilee.

The final events in preparationn the ministry of the Lord Jesus were significant found in the story of His transfer from Nazareth to Capernaum (where Nazareth was the residence of the Lord Jesus since childhood); Matthew sees it as an explicit fulfillment of the prophecy of Isaiah, as also contained in verse 14. Mark and Luke also mention the story of the move from Nazareth to Capernaum, but only Matthew explains it as a fulfillment of Isaiah's prophecy, the Zebulon region. and Naphtali was the area closest (or even) the territory of Galilee in the first century. The verse also gives a strong indication that Jesus is the light for those who live in the area, both non-Jews and Jews. ${ }^{4}$

After comparing with some of the earliest information that the Gospel of John revealed (information not recorded in Matthew), then the chronological story in 4: 12-17, occurred after He returned from celebrating Easter from Jerusalem (John 2); after conversing with Nicodemus (John 3). On his way home while in Judea, Jesus heard that John the Baptist had been arrested. Even when reading John 4: 1-2, it turns out that the Pharisees knew that Jesus' followers were far greater than John. So Jesus decided to leave Judea and go to Galilee. To get to Galilee, he must pass through the territory of Samaria. Where did he finally meet and converse with a Samaritan woman (John 4: 4-42). The context of Matthew 4:12 is the same as the context of John 4: 1-3.

But the events of Jesus going to Jerusalem (as recorded in John 2-3) are preceded by the events of Jesus being baptized by John the Baptist. Then He was tempted by Satan in the wilderness (Matt. 4: 1-11; Mark 1: 12-13; Luke 4: 1-13). After that some of John's disciples came and followed Jesus (John 1: 37-52); only then did Jesus make a miracle at Cana - the water turned into wine and a short trip to Capernaum (Matt. 2: 1-12) but not yet in the context of a missionary journey. Later, after John is captured and after He returns from Jerusalem, it can be said that Jesus' mission has been or is being begun.

When Matthew quoted the passage from Isaiah to declare the fulfillment of prophecy in and through the ministry of the Lord Jesus, it is clear from the construction of the sentence that the quote was not taken directly from the Masoretic Text but from the LXX. Blomberg agrees, but he adds I think with outs that Matthew in his translation still adjusts to the Hebrew context. Matthew returns parallelism by using the words 'land' twice before 'Zebulon' and 'Naphtali'. Matthew removes the clause that LXX added to the Masoretic Text, which is 'the

${ }^{4}$ Blomberg, Matthew on Commentary on The New Testament Use of The Old Testament, 18. 
road to the sea'. Matthew also returns the past indicative verbs, 'have seen' and 'have appeared' even in translations that seem to be more literal for the two phrases above. In addition, Matthew also uses the verb 'sit' to replace the two verbs, 'walk' and 'stay', perhaps an echo of Psalm 107: 10 or Isaiah $42: 7^{5}$

Based on what has been explained above, it can be said that even in terms of the use of the quoted words from Matthew it remains identical to the LXX in order to give the appearance of a literal dependence. What is expressed by Matthew turns out to have similarities with the LXX shows that there is a series of short phrases in which the translation used is evident. Thus it can also be seen here that there are no peculiarities of LXX that differ or conflict with the Masoretic Text. In short, Matthew indeed often quotes the Old Testament from the LXX; however, it also sometimes quotes the Hebrew Old Testament (Masoretic Text) directly.

\section{Explanation Matthew 4:16}

In verse 15 there is indeed no classification of Jesus' mission objects. However, looking at verse 16 it is clear that when Jesus arrived and settled in Capernaum, it not only had a positive impact on the Jews but also had an impact on the other nations that were there. The object of Jesus' mission is the Jewish people or Israel and other nations. This is evident in the construction of verse 16 which consists of singular and plural phrases. As shown below!

Single phrase: people living in sin have seen a great light. Matthew translates the word

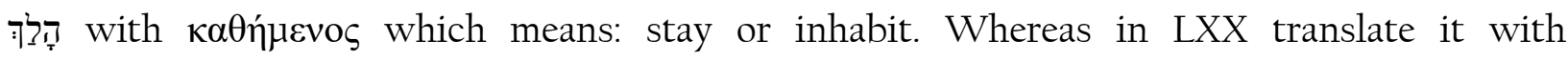
порєvó $\mu \varepsilon v o \zeta$ which means to walk.

The word הּד generally means: walk. And that means the translation given by LXX and Matthew is identical to the original text in the Masoretic Text. Although LXX and Matthew use

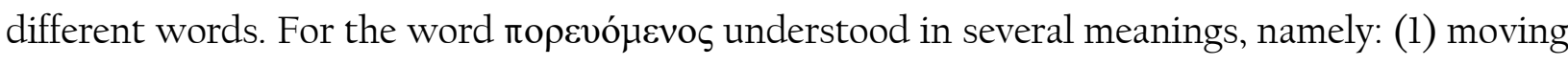
through an area with a certain starting point and destination; travel; (2) for one's own behavior; live or walk; (3) going to one's death. In the context of Isaiah 9: 1 it should be understood according to the second understanding, namely: the Jews of Isaiah's day did live or walk in the dark because at that time they lived in idol worship in Galilee.

Then in Matthew actually uses the word $\kappa \alpha \theta \eta \dot{\mu} \mu v$ o which is a participant form of the

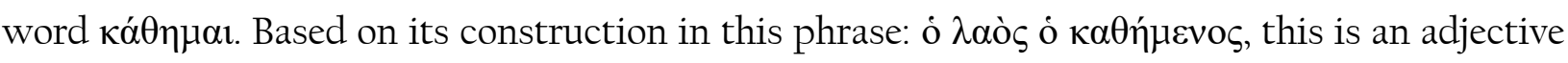
participant in the function as attributive. That means this word as an adjective that explains the noun in front of it. The word кá $\theta \eta \mu \alpha$ has several meanings, but in the context of Matthew 4:16

${ }^{5}$ Blomberg, Matthew on Commentary on The New Testament Use of The Old Testament, 19. 
it should be understood to be a resident of a place, living, being, living, living, and settled it down. That means that the Jews or Israel of Jesus' time who lived in Galilee were people who lived and lived in sin or lived in sin. Because the word $\dot{\varepsilon} v \sigma \kappa o ́ \tau \varepsilon \iota$ is understood in sin. Hagner commented, Jews lived in conditions of frustration and despair, and lived among idol worshipers from other nations. Osborne called it, "In spiritual darkness". However, Jews living in sin are inseparable from the influence of other nations who live alongside them in Capernaum. Osborne also emphasized that other nations actually lived or lived in spiritual darkness. ${ }^{6}$

Powell said, many historians now see Jesus as a Jew who had been greatly influenced by Greco-Roman culture. We know that the flow of Greco-Roman culture was very large at the time and place where Jesus lived. Yosepus tells us, for example, that some Jews in Palestine (under Roman rule) were willing to pay for surgical procedures that would release them from circumcision ... Apparently, Jews wanted to be like other nations, to assert their identity with the main reference to all human races rather than certain ethnic groups. Some scholars think that the influence of Hellenism was especially strong in Galilee, noting that the area of Jesus was called "Galilee, other nations" at one point (Matt. 4:15). They claimed, further, that the home of Jesus, namely: Nazareth was the main suburb of the great city of the Roman emperor, namely Sepporis, to which Jesus would be offered full complete weaponry of Greek and Roman society, a society where there would be mockers but there may not be many Pharisees. ${ }^{7}$ This means that the Galileans, including those living in Capernaum, had a mixture of Jews with other nations. This condition made the Jews who lived there could not avoid doing the same thing with other nations - who still lived in a tradition that did not know God.

The people who lived or lived in sin (spiritual darkness), when Jesus settled in Capernaum saw a great light. Matthew uses the word óó $\omega$ in the indicative active aoris (thirdperson singular - $\varepsilon \tilde{i} \delta \varepsilon v)$. That means it matches the word ò $\lambda \alpha$ ò $\varsigma$ which is also in a single nominative - so the subject of the word $\varepsilon \tilde{i} \delta \varepsilon v$ is ó $\lambda \alpha$ ò $\varsigma$. What's interesting here, because in the LXX translation of Isaiah 9: 1, the word óó $\omega$ is translated in imperative aoris ${ }^{8}$ active mode (plural second person - $i \delta \varepsilon \tau \varepsilon$ ). Based on that form, then in the context of Isaiah they will still wait for the light so they can see it. That is why it is made in the imperative mode. Even in the context of Isaiah, the prophet only looks at the Jewish people or Israel; later in the context of

${ }^{6}$ Grant Osborne, Exegetical Commentary on the New Testament (Grand Rapids, Michigan: Zondervan Publishing House, 2010),143.

${ }^{7}$ Mark Allan Powell, Jesus As A Figure in History (Louisville, London: Westminster John Knox Press, 1998), $170-71$

${ }^{8}$ According to Mounce, the aoris imperative tends to be used for special cases (specific orders), (William D. Mounce, Basics of Biblical Greek Grammar (Grand Rapids, Michigan: Zondervan Publishing House, 2009), 260). 
Matthew it will become clear that the fulfillment of this prophecy is not only intended for the Jewish people but also for other nations. ${ }^{9}$

Nevertheless this single phrase specifically addresses the Jewish people who settled in the Capernaum region. After all this time the people lived in sin; but when Jesus moved and settled there they saw a great light. Based on the word $\varphi \tilde{\omega} \varsigma$, large bright phrases ${ }^{10}$ understood figuratively which refers to the teachings and the person of Jesus. ${ }^{11}$ That means that Jesus presence in Capernaum is very urgent for the Israelites who are now living or living in sin. Because since Jesus came and settled in Capernaum, they have seen salvation through the light of the Gospel delivered by Jesus to them. ${ }^{12}$ Bock added, "Luke and Matthew have already shown the Messiah as light, the bringer of God's righteous deliverance - Luke 1: 78-79; Matthew 4: 1216. ${ }^{13}$ That means that when light figuratively affirms the presence and teachings of Jesus, it also affirms Jesus as the Messiah.

Then plural phrases: too [The conjunction kai confirms that the two phrases (single phrase and plural phrases) are equivalent sentences. Although the second phrase begins with the dative form; but isn't that phrase in the phrase itself: $\varphi \tilde{\omega} \varsigma \dot{\alpha} v \varepsilon \dot{\tau} \varepsilon \imath \lambda \varepsilon v]$, (and) the light has shone for those who live in the land in the shadow of death. From this phrase it is understood that Jesus' presence in Capernaum did not only bring salvation to the Jews who lived in sin. But also for other nations that are there. Because based on this plural phrase, the purpose of Jesus' coming and settling in Capernaum is for them. Also with the teachings of Jesus which is intended for them. ${ }^{14}$

\footnotetext{
${ }^{9}$ According to LaGrand, "The full meaning of the Galilean mission is now announced and will be explained in the words and deeds of Jesus the Messiah. Projections of significance in world missions through His disciples have been indicated in the 'inauguration' of Jesus' teaching on the hill ('You are the light of the world' - Matt. 5:14) and finally planned in the Great Commission, (James LaGrand, The Earliest Christian Mission to "All Nations" in the Light of Matthew Gospel (GrandRapids, Michigan: William B. Eerdmans Publishing Company, 1995), 185).

${ }^{10}$ Stanton said, in Matthew, Christology and Ecclesiology often involved interrelation. In 4: 15-16, appears before the Sermon on the Mount; Matthew quotes Isa.9: 1-2 with the aim of describing Jesus as promised - for Galilee, the Gentiles. At an important point in the structure of the Sermon on the Mount, students are given a

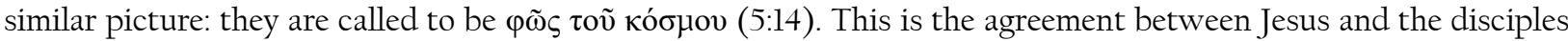
in all of a passage with the evangelist's insistence that the disciples' preaching and healing actions are closely modeled on Jesus himself (10: 1, 7, 8), (Graham N. Stanton, A Gospel For A New People: Studies In Matthew (Louisville, Kentucky: Westminster/John Knox Press, 1992), 321).

${ }^{11}$ Friedrich. Kittel, ed., Theological Dictionary of The New Testament (TDNT) Volume One (Grand Rapids, Michigan: Eerdmans Publishing, 1985), 1297.

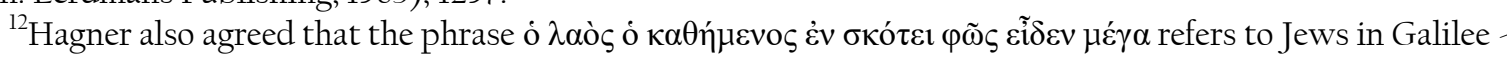
$\lambda \alpha$ ò $̧$ elsewhere in Matthew is used only for Israel, (Donald A. Hagner, Word Biblical Commentary (WBC): Matthew 1$13,74)$.

${ }^{13}$ Darrell L. Bock, Jesus: According to Scripture (Grand Rapids, Michigan: Baker Academic, 2002), 411.

${ }^{14}$ Stanton said, at 4:16 a quote from Isaiah 9: 1-2 used an introduction to Jesus' mission: "the people who sat in the region and the shadow of death light has dawned". Jesus' coming is a light for those who need it; in this verse which follows the Gospel writer's emphasis that Jesus healed illnesses and those with all kinds of mental and physical disabilities, (Stanton, A Gospel For A New People: Studies In Matthew, 373).
} 
The word $\dot{\alpha} v \varepsilon \dot{\tau} \tau \varepsilon \lambda \varepsilon \varepsilon v$ which is an active third person singular indicative aoris form of the word $\alpha \dot{v} \alpha \tau \dot{\varepsilon} \lambda \lambda \omega^{15}$. Where in this context is understood as 'moving up or appearing'. ${ }^{16}$ This means that salvation from God brought by Jesus through teachings even by Himself has arisen or has dawned for other nations in Capernaum along with Jesus' arrival and residence. This rising of light becomes something urgent for them because they live in the country in the shadow of death. The word $\sigma \kappa i \alpha$ in the context of Matthew 4:16 is understood as territory and the shadow of death refers to other nations (Gentiles) for whom the Messiah came himself in the light of eschatological salvation. ${ }^{17}$ That means the death referred to in this verse is death due to sin or what is often referred to as spiritual death. As is clearly seen in the meaning of the word $\theta$ ávatos in this context as death which is seen as very contrary to life that is related to God. ${ }^{18}$

However, not all interpreters agree that Jesus' mission to Capernaum or Galilee also addressed to other nations. As Hagner in his interpretation explains verse 16 only for the Jewish context. Or in other words, Jesus came and settled in Capernaum solely to carry out the mission to the Jews.

However, taking into account the context of Matthew and some of Jesus' missionary events while in Galilee, the opinion of Hagner above can still be disputed. Because on several occasions it shows that Jesus did not distinguish between Jews and other nations. As noted in John 4: 46-54, when Jesus healed the palace servant's son (not Jewish) in Capernaum; and the miracle was Jesus performed at a distance (from Cana). Even when he was still in Nazareth (before going away to Capernaum) when Jesus mentioned Elijah's ministry to a widow in Zarephath (in Sidon) and Elisha's service to Naaman, the Syrians. In fact, he was asserting that even his mission to Galilee, especially to Capernaum was not meant for Jews alone. When there are people from other nations who believe, then that person will definitely be saved by Him.

But it needs to be known that the mission to other nations in Galilee should be understood as a mission that has not been systematic. That is, Jesus came there with the aim of finding and saving the lost Israelites there. But then, as the canonical gospels have witnessed, it turns out that not all of the Israelites accepted Jesus' mission. So this has an impact on the

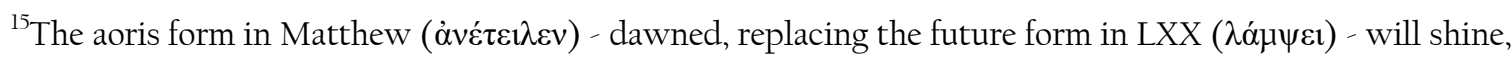
tense perfect in the Hebrew text (Masoretic Text), whereas Matthew has his own perspective, (Donald A. Hagner, Word Biblical Commentary (WBC): Matthew 1-13, p. 73-74). The difference in tense in this word makes sense because Matthew sees Jesus as the fulfillment of the prophecy in Isaiah. Isaiah still will but Matthew already. Because Jesus has come and has stayed in Capernaum to carry out His mission.

${ }^{16}$ Walter Bauer's, A Greek-English Lexicon of The New Testament And Other Early Christian Literature (BDAG) Third Edition., ed. Frederick William Danker. (Chicago: The University of Chicago Press, 2000), 73.

${ }^{17}$ Kittel, Theological Dictionary of The New Testament (TDNT) Volume One, 1046.

${ }^{18}$ Bauer's, A Greek-English Lexicon of The New Testament And Other Early Christian Literature (BDAG) Third Edition, 442-443.
} 
transfer of that blessing to other nations as well. The blessing that should belong to the nation of Israel itself, then finally shared with other nations. And if you pay attention to the context of the whole gospel, then the blessing for other nations is crumb. Or the remains that were rejected or dropped from their table (the Israelites) compare Matthew 15: 21-28.

\section{Situation of Galilean Demographics in the Age of Jesus}

Why not discuss Galilee after the time of the Lord Jesus? This is inseparable from the purpose of the discussion this section is to bring the writer and reader to understand and understand the situation and conditions of Galilee before the time of the Lord Jesus - so that it can become a correct knowledge of Galilean background.

Thus, this discussion will lead to understanding the purpose and meaning of identifying Galilee as other nations based on biblical historical aspects.

\section{Before the Age of the Lord Jesus}

In this section, the author will focus his discussion on two points namely: Galilee under Greek rule and under Jewish rule. There is also the purpose of this discussion to find a comprehensive understanding of the condition of Galilee demographically in chronological history from the time of the Old Testament to the time of the Lord Jesus.

Galilee under Greek rule. The massive expansion undertaken by Alexander the Great into the Eastern Mediterranean region directly impacted directly the power of the Persian government in the region. Chancey argued, trade relations with the Greeks were seen in Palestinian archeological records from the Persian period, and the conquest by Alexander the Great in the subsequent period resulted in increased interaction between Greek culture and local culture. ${ }^{19}$ Based on Chancey's view above, there is a strong indication that there has been a mixing of cultures - including that with Galilean culture.

Chancey also stated that, "Galilee's population under Greek rule probably also included Phoenicians, as well as a few Itureans (particularly in the northern regions), and some Jews. The population of the region was gradual, occurring over centuries, and seemingly not the result of any intentional efforts by the various ruling powers, none of whom introduced a substantial number of colonists". ${ }^{20}$ The Galilean population during Greek rule naturally formed in a relatively long duration of time - gradually over centuries. Consisting of Phoenicians, Iturians

\footnotetext{
${ }^{19}$ Mark A. Chancey, The Myth of A Gentile Galilee (Cambridge: The Press Syndicate of The University of Cambridge, 2004), 35.

${ }^{20}$ Chancey, The Myth of A Gentile Galilee, 167.
} 
(especially in the northern regions), and some Jews. This formation was formed not through an intentional aspect or because of a policy. That means, at this time the Galilee region became a region that was free to be visited by tribes around the region. So that over time, those who came there finally settled and became residents of Galilee.

Then after Alexander the Great died ${ }^{21}$, his successors divided the kingdom among themselves. And according to A.A. Jones, Galilee became one of the arenas of conflict between the Ptolemaic dynasty and the Seleucids. ${ }^{22}$ The two kingdoms above were later adopted as the name of a place or city. These cities are on the border with Galilee and the surrounding area. Sean Freyne argued, the Ptolemaic dynasty established cities, such as establishing Ptolemais on the coast of Acco, Scythopolis in Beth She'an in the southeast of the plains of Galilee, and Philoteria in the Southwest of the Sea of Galilee - possibly Beth Yerah. ${ }^{23}$ Added by Freyne, in a typical Hellenistic form, Seleukos has changed several city names in Palestine. For example, by adding 'Nysa' in front of the name Scythopolis. In addition, Seleukos also established new cities, such as Antioch to the north near Paneas, and Seleukia in the Golan. ${ }^{24}$

Based on the above information, it can be said that in this period there was little reason to admit that there had been some demographic changes in the Galilee and surrounding areas. Although in the Galilee region itself it is not so significant. It is possible that foreigners had settled in areas on the outskirts of Galilee, such as: Scythopolis ${ }^{25}$, Philoteria, Ptolemais. Likewise with the regions around Galilee, such as: Antioch and Seleucia.

Galilee was under Jewish rule. This period can be said to begin with Yonathan Maccabee (153-143 BC) defeating the Seleucid imperial army through the Maccabean revolt in 165 BC. Two decades after the conquest, through his brother, Simon Maccabees (142-134 BC) the Hasmonean dynasty was established. The Hasmonean Empire survived until 103 BC, before it was finally conquered by the Herod dynasty.

\footnotetext{
${ }^{21}$ According to Peter Green, after the death of Alexander the Great, his empire was divided into four regions, namely: the Ptolemaic Kingdom in Egypt, the Seleucid empire in Persia, the Pergamon Kingdom in Asia Minor, and the Kingdom of Macedonia in Greece, (P eter Green, Alexander the Great And The Hellenistic Age (Orion Books, 2007), 29-45).

${ }^{22}$ A.H.M. Jones, The Cities of the Eastern Roman Provinces (Oxford: Clarendon Press, 1971), 226-56.

${ }^{23}$ Sean Freyne, Galilee From Alexander the Great to Hadrian: 323 BCE to 135 CE: A Study of Second Temple Judaism (Edinburg: T\&T Clark, 1998),104-14.

${ }^{24}$ Jones, The Cities of the Eastern Roman Provinces, 113-14.

${ }^{25}$ Scythopolis was formerly called Beth Shean. A city in the territory of Issachar was given to Manasseh where the Canaanites were not driven away (Josh. 17:1l; Jd.l: 27). In the days when the Israelites were strong, they were punished by compulsory labor (Judges 1:28). They believed that they were in fellowship with the Philistines who after the defeat of the Israelites at Gilboa while nailing the corpses of Saul and his children to the city wall (1 Sam. 31: 7-13); from where the people of Jabesh Gilead took the bodies, then burned and buried their bones under the Tamariska tree in Jabesh. In 1 Kings 4:12 the name applies to the district in which the city stood. The city was called Scythopolis by the Greeks. This name may be related to the invasion of Palestine by Scytian.
} 
Based on historical records in 1 Maccabees 5: 9-23 confirm this period was an important period in forming the population of Galilee. As stated by J.C. Dancey that the historical account in 1 Maccabees above contains about the military activities of Simon Maccabees in Galilee, placed in a larger report about the rescue of Jews in Galilee and Gilead, often referred to as the Maccabean uprising, Jews as a minority in a region known with 'Galilee are other nations'. ${ }^{26}$ This story begins with the other nations that were hostile to the Jews. Then the Galilean delegation went to Jonathan and his brother claiming that the people of Ptolemy, Tire and Sidon, and all the other peoples of Galilee had gathered together to fight them - with the intention of exterminating them. Finally Simon Maccabee went to Galilee and fought against the gentiles there - apparently he succeeded in defeating them. However, because he was unable or perhaps unwilling to hold the area, Simon then pulled the Jews from Galilee back to Jerusalem. Emil Schürer gave his opinion that about the Simon Maccabean invasion of Galilee it was very clear that the Jews in Galilee and Gilead were still a diaspora among other nations, and initially Maccabees going there did not intend to prosecute the region, but rather things instead he did, by pulling the Jewish population from there. ${ }^{27}$ If this information is true, then the evacuation of the Jews carried out by Simon Maccabees - we can be sure that the area will eventually be inhabited entirely by other nations. And this condition may continue for decades to come.

Chancey refuted the above assumption that all Jews had left the Galilee region after the victory of Simon Maccabees against other nations in the region. For him there is not enough evidence or sufficient reason to conclude the condition. Chancey's opinion above is contained in the explanation below,

Only the most basic: Galilee was outside the sphere of control of the early Maccabean leadership, though they were willing to venture north occasionally. Aside from the campaign recorded in 1 Maccabees 5:9-23, all action in Galilee occurs between Maccabean forces and Syrians, not with local gentiles. If the report of the expedition to Galilee in 1 Maccabees 5:9-23 is accurate, it indicates only that conflict between Jews and gentiles occured near the coastal region. It account of a complete evacuation of Jews is especially suspect, given its usefulness for portraying the Maccabees as the fulfillers of biblical promises of the ingathering of the Jews to Jerusalem. In any case, whether chapter five is historically reliable or not, it allows us to make few generalizations about Galilee's population. We cannot tell what proportion of the population was Jewish before Maccabees, and we cannot assume that all Jews left Galilee during the wars of Jonathan and Simon. ${ }^{28}$

\footnotetext{
${ }^{26}$ J.C. Dancey, A Commentary on 1 Maccabees (Oxford: Basil Blackwell, 1954), 104.

${ }^{27}$ Emil Schürer, The History of The Jewish People in The Age of Jesus Christ (Edinburg: T\&T Clark, 1987), 142.

${ }^{28}$ Chancey, The Myth of A Gentile Galilee, 41.
} 
Chancey's opinion above explains that in the early Maccabean period it turned out that the Galilee territory was beyond the control of the Maccabean leadership, even though they sometimes visited the North. For him the war fought by the Maccabees was not against the other peoples who settled in Galilee, but with the Syrian troops who were in Galilee at that time (cf. 1 Maccabees 5: 9-23). If it is true that every event recorded or reported in 1 Maccabees 5: 923, all this shows only conflict between Jews and other nations, and it happened near the coast.

To question the validity of information stating that there had been a massive evacuation of Jews to Jerusalem. Because for Chancey, it is worth remembering that the function of the Maccabees themselves is as the fulfillment of the Bible's promise in gathering Jews to Jerusalem. Chancey could not be sure of the number of Jews in Galilee before Maccabees - and could not assume that all Jews had left Galilee during the Jonathan and Simon wars.

Chancey's explanation above seems more reasonable, because it is not possible for all Jews to have left the Galilee region. Because if you look at the following periods, you will find that there are still Jews there.

The following period, as has been known in history that the territory of Galilee remained beyond the control of the Hasmonean dynasty for at least the next few decades. Although it must be acknowledged several times to invade even often win when fighting against the North because the Hasmoneans are based in Jerusalem (the South). John Hyrcanus ${ }^{29}$ often invading north even to the north of Samaria, like the surrounding Scythopolis. However, the Galilee region was never under Hasmonean rule until Hyrcanus died. It was only after the reign of Aristobulus I (son of Hyrcanus) before the Galilee territory was conquered and came under Hasmonean $^{30}$ control. Although in fact he was in power only in a relatively short time (104-103 $\mathrm{BC})$.

Chancey himself argues that the conquest of Aristobulus of the Galilee region was a very important turning point in understanding the population of the Galilee population in the next hundred years at the beginning of the New Testament era. ${ }^{31}$ And the information obtained earlier in 1 Maccabees 5, it is still assumed that only a few Jews were brought to Jerusalem - even

\footnotetext{
${ }^{29}$ John Hyrcanus is the son of Simon Maccabees. Hyrcanus had sons named Aristobulus I and Alexander Jannaeus. John Hyrcanus came to power in the Hasmonean dynasty in 134-104 BC.

${ }^{30}$ Some scholars assume that the Hasmonean dynasty was a little soft on the Itureans and Idumeans, which they actually conquered. Who are the Idumeans and Itureans? They were Arabs who actually settled in the north and north of the sea from Galilee, precisely around Mount Lebanon. They took advantage of the Seleucids' weaknesses, and began to migrate into Galilee - even to the mountains of Hermon and Golan. Based on this, there is a strong indication that there has been a mixture of the Galileans with the Itureans, (Chancey, The Myth of A Gentile Galilee, 44).

${ }^{31}$ Chancey, The Myth of A Gentile Galilee, 42.
} 
though the number is not known with certainty. It is interesting to pay attention to what Chancey said about this period,

In discussions of Aristobulus's imposition of Judaism in Galilee, scholars have often focused on the fate of those gentiles who close to remain on their land. The archaeological evidence, while admittedly not yet extensive, suggests that many chose to escape Jewish rule altogether, abandoning their communities and fleeing into the surrounding areas. The appearance of new sites in the late Hellenistic era suggests that new settlers moved into Galilee, the most likely candidates being Judean colonists. Perhaps they came to reclaim ancestral territory, or perhaps they were attracted by Galilee's climate and arable land. In any case, the expanded settlement which began in the late Hellenistic period continued into the Roman period. ${ }^{32}$

The majority of scholars are more focused on the fate of other nations in the Galilee region, when alluding to this point. Thus, from Chancey's information above, it can be clearly seen that during the Hasmonean dynasty there were indeed many Jews who fled to the Galilee and beyond. Based on very limited archeological evidence, the emergence of new sites at the end of the helenistic era shows that the new settlers had moved to Galilee - and possibly there was a group from Judea. There is also a reason why they moved there is unclear. Do they want to reclaim ancestral territory that has been lost or maybe they are interested in the climate of Galilee and the fertility of the land.

Based on the information above, it is concluded that there is a strong indication that there has been a mixture of other nations that already existed in Galilee with the Jews (possibly from Judea) who then migrated to Galilee in the Hasmonean dynasty period. Thus it can shed some light on why later in the days of the Lord Jesus in Galilee there were still Jews and even synagogues were still there, but were identified as the territories of other nations. Such conditions must be motivated by the dynamics of the population of the Galilean population from the Old Testament to the Hasmonean dynasty.

As such, it still needs to look at another period, the period of Roman rule - during which the Hasmonean dynasty was replaced by the Herod dynasty. This period also became the period when the Lord Jesus lived and served in Galilee.

\section{Towards and During the Age of the Lord Jesus}

In this section begins since the Herod dynasty succeeded in defeating the Hasmonean dynasty - as well as the start of the invasion of the Roman empire into the territory of Israel and beyond. After the death of Salome, who was the successor of Jannaeus; chaos and power

\footnotetext{
${ }^{32}$ Chancey, The Myth of A Gentile Galilee, 47.
} 
struggles in the subsequent Hasmonean dynasty. In the midst of this political turmoil, precisely in 63 BC; Pompey came and attacked Palestine - thus automatically impacting political change in the region. Jerusalem is under siege, Aristobulus II is detained to Rome, even Pompey can regain the territory of Rome that was captured during the Hasmonean dynasty in power.

The list of areas captured by Rome again explained by Chancey in his books such as: Hippos, Scythopolis, Pella, Samaria, Jamnia, Marisa, Azotus, Arethus, Gaza, Joppa, Dora, Tower of Strato. Josephus's opinion as quoted by Chancey, all the cities were returned to the legal population and annexed to the Syrian province. Although some other areas in Galilee remained under Jewish rule, such as: Sepphoris. ${ }^{33}$

Added again by Chancey, even before Aristobulus II was fully defeated there had been a reorganization in the Palestinian territories. Marked with Gabinius dividing the region into five regional council areas based in Jerusalem, Gadara, Amathus, Jericho, and Sepphoris. Sepphoris's election as the administrative capital for the Galilee region shows the region's superiority. When Pompey arrived in Palestine, conflicts sometimes arose as a result of certain factions trying to control the region. The attack from the Partian territory also added to the situation there. Again Galilee became a battlefield, although occasionally it also took place on Mount Tabor and occasionally the Taricheae, the place where Cassius had enslaved thirty thousand Jews. ${ }^{34}$

In his book entitled Greco-Roman Culture and the Galilee of Jesus; Chancey notes, even though Galilee was annexed by Pompey in 63 BC, it still remained outside Roman influence. As in previous periods, most of life was focused on hilly areas such as: Khirbet Qana and Meirot. While in the Judean, Phoenician and Decapolis regions large-scale development programs and transformations were being carried out by the emperor, the military and the elite. ${ }^{35} \mathrm{M}$. H. Jensen in his writings also emphasized that there is no place in Galilee that shows that there has been a transformation or development program found by experts. Even Herod Antipas, who was considered to have a strong influence in Galilee, had only undertaken simple construction.

Thus, Roman rule did not have a direct influence on life in Galilee. Chancey states that, the historical development of Galilee does not indicate that the beginning of Roman rule; Galilean inhabitants have experienced mixing - even showing the opposite condition. In the first century,

${ }^{33}$ Chancey, The Myth of A Gentile Galilee, 47-48.

${ }^{34}$ Chancey, The Myth of A Gentile Galilee, 48.

${ }^{35}$ Chancey, The Myth of A Gentile Galilee, 73-82. C.T. McCollough and D.R. Edward put forward the reasons why the construction was carried out by the Roman government in Galilee. According to him, because the Roman government had granted autonomy to the Galilean region after the annexation of Syria. Then because the Roman government did not directly involve itself in the area on the grounds that Herod Antipas had been placed there as an emperor's client. In addition, the problem of geography also became an obstacle, where the Galilee region was almost isolated from access by outsiders because of its location on the outskirts of the mountains of Lebanon. This condition is then exacerbated by the infrastructure that connects with the very small neighboring regions.. 
it seems that the inhabitants of Galilee were predominantly Jewish, with only a few pagan people. $^{36}$

Freyne also gave a little information about the relationship of urban areas with villages in Galilee in the first century in his article titled Urban-Rural Relations in First-Century Galilee: Some Suggestions from the Literary Sources. He commented that, in all four models, social relations were more dominant in seeing the relationship between cities and villages. Based on economic patterns and social unity there has been considerable evidence that both Greece and Herodian cities in the first century Galilee were heterogeneous in terms of intercultural exchange, due to earlier and broader relations with Jerusalem, the orthogeneous city, which had long been with the population this city.

Conclusion. If you trace back the history of the past, then it is certain that it is very unlikely that the first century Galileans were descendants of the Israelites before the conquest of the Assyrians - remembering that at that time the Assyrians also had depopulated. After the death of Alexander the Great, the impact of the Ptolemaic and Seleucid dynasties on the composition of the population in Galilee was very small.

The most likely thing is that some of the inhabitants of Galilee came from Phoenician and Iturean ancestry. Why is this so possible? Remembering before the Hasmonean dynasty, there had been a massive migration to the empty regions of Galilee carried out by groups that were or lived around that area. But there were Jews who also became residents of Galilee in the first century AD. Most likely they went there during the conflict during the Maccabean period.

After the annexation of the Galilee region gives a strong indication that a new chapter in the history of Galilee has begun. Because after that it shows that many of the Galileans had decided to stop submitting to the rules set before the Hasmonean dynasty. In addition, the Hasmonean dynasty had introduced new settlers, even Jews had dominated the Galilee region. ${ }^{37}$ Although it must also be recognized that in Galilee in the first century there were also several other nations.

The presence of Jews in the Galilee region before or at the time of the Lord Jesus is also supported by a lot of evidence or information from the New Testament. For example in John 4:45, when the Lord Jesus arrived in Galilee it turned out that the Galileans welcomed him well; because they have seen all the deeds or miracles that He has performed in Jerusalem. That is, they are Jews who every year at certain times to Jerusalem celebrate the Jewish feast.

\footnotetext{
${ }^{36}$ Chancey, The Myth of A Gentile Galilee, 61.

${ }^{37}$ Chancey, The Myth of A Gentile Galilee, 62.
} 
Based on information from several literatures, one of which is the Dictionary of the Later New Testament and Its Development, it can be said that at this time (first century) Galilee was inhabited by Jews, Romans, Greeks, Syrians, Phoenicians, Samaritans, Arabs, and Egyptians. Even though the Jewish law prevailed at that time, the Jews continued to live side by side in harmony with the non-Jews. Perhaps this is due to their tolerance and openness with non-Jews who socialize and associate with them every day.

\section{Result}

In verse 16 this also shows clearly the tendency of Jesus' mission not only to the Jews, but also to other nations. Stanton says, the quote from Isaiah 9: in Matthew 4: 15-16

The nation that dwells in sin has seen a great light,

also the light has shone on those who live in the land in the shadow of death.

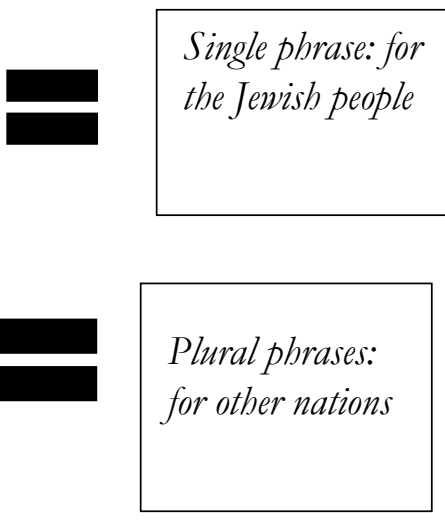

Chart: Single-plural Formulation in verse 16

also similarly functions. The preamble of Jesus' mission in Galilee, and especially in Capernaum, was seen as fulfilling Scriptural prophecy (OT). But the selection of the Gospel writers from this quote is dictated by another consideration: in the number of messages in his gospel, he emphasizes that the story or story of Jesus means its ultimate meaning for other nations and the Jewish people. References (though not directly) coming kedatangan are also related to Matthew's main concern. Jesus here is called (indirectly) $\varphi \tilde{\omega} \varsigma$ for Galilee, the Gentiles; His

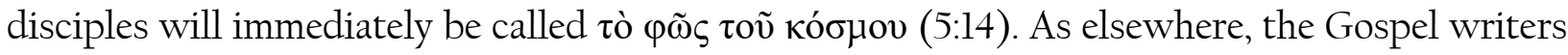
describe the attention to two ways in which His disciples (and Christians in time) continued the mission of Jesus. ${ }^{38}$

Because in verse 16 comes the singular and plural phrases; it is understood that the single phrase refers to the Jews who lived in Capernaum or Galilee in general - while the plural phrases are intended for other nations. That is why the presence and message of Jesus there was not only intended for Jews - but also for other nations. The light of the gospel not only enlightens the Jews but also for other nations who want to believe. Freedom from sin and death will not only be enjoyed by the Jews, but also other nations. So it is not wrong to mention that the mission to Galilee (especially Capernaum) was a mission to other nations.

\footnotetext{
${ }^{38}$ Stanton, A Gospel For A New People: Studies In Matthew, 362.
} 


\section{Conclusion}

After examining the two phrases in verse 16 and considering the historical context or the demographic situation of Galilee at the time of Jesus, it can be stated that Jesus' mission to Galilee was aimed at the Jews and other nations who were there and had long lived there.

Thus, the meaning of the singular and plural phrases in that verse are: the single phrase is intended for Jews and the plural phrases for other nations. Thus, it can provide a theological understanding that Jesus' mission in Galilee was not only for the Jews who were there, but also for other nations that had long settled there even before the time of Jesus.

\section{Bibliography}

A.H.M. Jones. The Cities of the Eastern Roman Provinces. Oxford: Clarendon Press, 1971.

Bauer's, Walter. A Greek-English Lexicon of The New Testament And Other Early Christian Literature (BDAG) Third Edition. Edited by Frederick William Danker. Chicago: The University of Chicago Press, 2000.

Blomberg, Craig L. Matthew on Commentary on The New Testament Use of The Old Testament. Grand Rapids, Michigan: Baker Academic, 2007.

Bock, Darrell L. Jesus: According to Scripture. Grand Rapids, Michigan: Baker Academic, 2002.

Chancey, Mark A. The Myth of A Gentile Galilee. Cambridge: The Press Syndicate of The University of Cambridge, 2004.

Dancey, J.C. A Commentary on 1 Maccabees. Oxford: Basil Blackwell, 1954.

Donald A. Hagner. Word Biblical Commentary (WBC): Matthew 1-13. Printed in Colombia: Nelson Reference and Electronic, 1993.

Green, Peter. Alexander the Great And The Hellenistic Age. Orion Books, 2007.

Kittel, Friedrich., ed. Theological Dictionary of The New Testament (TDNT) Volume One. Grand Rapids, Michigan: Eerdmans Publishing, 1985.

LaGrand, James. The Earliest Christian Mission to "All Nations" in the Light of Matthew Gospel. GrandRapids, Michigan: William B. Eerdmans Publishing Company, 1995.

Mounce, William D. Basics of Biblical Greek Grammar. Grand Rapids, Michigan: Zondervan Publishing House, 2009.

Osborne, Grant. Exegetical Commentary on the New Testament. Grand Rapids, Michigan: Zondervan Publishing House, 2010.

Osborne, Grant R. The Hermeneutical Spiral: A Comprehensive Introduction to Biblical Interpretation. USA: 
InterVarsity Press, 2006.

Powell, Mark Allan. Jesus As A Figure in History. Louisville, London: Westminster John Knox Press, 1998.

Schürer, Emil. The History of The Jewish People in The Age of Jesus Christ. Edinburg: T\&T Clark, 1987.

Sean Freyne. Galilee From Alexander the Great to Hadrian: 323 BCE to 135 CE: A Study of Second Temple Judaism. Edinburg: T\&T Clark, 1998.

Stanton, Graham N. A Gospel For A New People: Studies In Matthew. Louisville, Kentucky: Westminster/John Knox Press, 1992. 